\title{
STUDIES OF DOSIMETRY PROTOCOLS FOR ACCELERATED PHOTONS AND ELECTRONS DELIVERED FROM MEDICAL LINEAR ACCELERATOR
}

\author{
(D)A.K.M. Moinul Haque Meaze,*, (DSantunu Purohit ${ }^{a}$, (D). Shakilur Rahman ${ }^{\mathrm{b}}$, \\ (D)Abdus Sattara, (DS.M. Enamul Kabirc, (DMd. Kawchar Ahmed Patwaryd, \\ DKamrunnahar Kalid, (D)Md. Jubayer Rahman Akhand \\ ${ }^{a}$ Department of Physics, University of Chittagong, Bangladesh \\ ${ }^{b}$ Secondary Standard Dosimetry Laboratory, Bangladesh Atomic Energy Commission, Savar, Dhaka, Bangladesh \\ ${ }^{c}$ National Institute of Cancer Research, Dhaka, Bangladesh \\ ${ }^{d}$ Department of Physics, Comilla University, Bangladesh \\ ${ }^{e}$ Bangladesh Military Academy, Bhatiary, Chittagong, Bangladesh \\ *Corresponding Author:meaze@cu.ac.bd;mhqmeaze@yahoo.com \\ Received October 22, 2020, accepted December 15, 2020
}

We focus on the comparative study of dosimetry protocols in radiotherapy for accelerated photon and electron delivered from medical linear accelerator (LINAC). In this study, a comparison between the protocols (TRS 398, DIN 6800-2 and TG 51) for both the electron and photon delivered from Clinac 2300CD and Clinac DHX 3186 were performed. We used photon beams with energies of 6 and 15 $\mathrm{MV}$ and electron beams of 4, 6, 9, 12, 15 and $18 \mathrm{MeV}$ for both Medical Linac. In case of Clinac the maximum deviations for the relative dose at $\mathrm{D}_{\max }$ for the photon beam (15 MV) among the protocols was observed to be $1.18 \%$ between TRS-398 and TG-51, $1.56 \%$ between TG-51 and DIN $6800-2$; and $0.41 \%$ between TRS-398 and DIN $6800-2$. Conversely, these deviations were $3.67 \%$ between TRS-398 and TG-51, 3.92\% between TG-51 and DIN 6800-2 for $4 \mathrm{MeV}$ and $0.95 \%$ between TRS-398 and DIN $6800-2$ in the case of Clinac $2300 \mathrm{CD}$ for the PTW Markus and Exradin A10. For the measurement of the maximum absorbed dose depth to water using three protocols, the maximum deviations were observed between TRS 398 and TG-51 as well as TG51 and DIN 6800-2.

KEYWORDS: TRS (Technical Report Series), TG (Task Group), DIN (Deutsches Institut für Normung).

Approximately $60 \%$ of cancer patients are referred for external beam radiotherapy, for which the most commonly used equipment is a medical LINAC that produces an electron beam and photon beam [1]. The precise planning of the treatment depends on the tumor type, size, position, stage, and health condition of patients [1,2]. By considering various uncertainty components associated with beam calibration factors, a study of the uncertainty in determining of the absorbed dose to water had been carried out by C. Pablo et.al. [3] Their results showed a typical uncertainty in the determination of absorbed dose to water during beam calibration approximately $1.3 \%$ for photon beams and $1.5 \%$ for electron beams ( $k=1$ in both cases). M. S. Huq et. al. [4] performed a study by comparing International Atomic Energy Agency Technical Report Series No. 398 (IAEA TRS-398) and AAPM TG-51 absorbed dose to water protocols in the dosimetry of highenergy photon and electron beams. They compared the two protocols in two ways: (i) by analyzing the differences of the basic data included in the two protocols for photon and electron beam dosimetry in detail and (ii) by performing experiments in clinically accelerated photon and electron beams and determining the absorbed dose to water following the recommendations of the two protocols [4]. For electron beams, the ratios TG-51/TRS-398, of the absorbed dose to water $\mathrm{D}_{\mathrm{w}}$ were observed to be lie between 0.994 and 1.018 depending upon the chamber and electron beam energy used, with mean values of $0.996,1.006$, and 1.017 respectively, for the cylindrical, well-guarded and not well-guarded planeparallel chambers [4]. A dosimetric study comparing NCS report-5, IAEA TRS-381, AAPM TG-51 and IAEA TRS-398 in three clinical electron beam energies was carried out by H. Palmans et. al. [5]. In their work, they compared dosimetry for three clinical electron beam energies using two NE2571-type cylindrical chambers, two Markus-type plane-parallel chambers and two NACP-02-type plane-parallel chambers [5]. Another comparison of high-energy photon and electron dosimetry for various dosimetry protocols was performed by F. Araki et. al. [6] They calculated the absorbed dose to water calculated according to the Japanese Association of Radiological Physics, IAEA TRS-277 and IAEA TRS-398 protocols, and compared it to that calculated using the TG-51 protocol. A comparison of protocols for external beam radiotherapy beam calibrations was carried out by S S Al-Ahababi et. al. [7] where they used the IAEA TRS-398, AAPM TG-51 and IPEM 2003 protocols. The comparisons were carried out by delivering electron beams of nominal energies of 6, 9, 12, 16 and $20 \mathrm{MeV}$ using Physikalisch-Techische Bundesanstalt (PTW) Markus and NACP-02 plane-parallel chambers.

Different group of dosimetrists did experiments several times to ensure lower uncertainty, best suited protocols and improvement of protocols for the commissioning of medical Linac and more precisely healthcare purposes. The aims of our work is to analyze the dosimetry applying three different most preferable protocols maintaining the QA parameters for high energy photon and electron beams delivered from the medical linear accelerator (Clinac). Different ionization chambers were used to calculate the absorbed dose to water and a comparison among chambers was investigated. For each chamber the absorbed dose to water was calculated using three different protocols. Sometimes in same reference conditions absorbed dose differs from Clinac to Clinac because of wall material of jaws. To confirm that dose variations 
we use two different medical LINAC and same chamber response with LINAC in this research work. This study will be helpful for defining more accurate dosimetry and developing more general protocol for ensuring patient safety during treatment planning.

\section{METHODS AND MATERIALS}

\section{Absorbed dose to water calibration in ${ }^{60} \mathrm{Co}$}

The calibrations in terms of absorbed dose to water are available only for ${ }^{60} \mathrm{Co}$ gamma radiation [8]. The reference point of the chamber was at $5 \mathrm{~g} / \mathrm{cm}^{2}$ water depth. The size of the radiation field (50\% isodose level) at the reference plane was $10 \mathrm{~cm} \times 10 \mathrm{~cm}[9-12]$. The PTW Markus chamber was set up for determining the calibration factor in a water phantom, and then the Physikalisch-Techische Bundesanstalt (PTW) UNIDOSE electrometer was used to obtain the dose rate. From these dose rates the calibration factor was measured using the IAEA TRS-398 protocol. The same procedure was used to calibrate the Exradin A10 and IBA FC65-G (2009) chambers. The descriptions of different protocols are presented in Table 1.

Table 1. Description of different protocols $[10,13,14]$

\begin{tabular}{|c|c|c|c|c|c|c|c|}
\hline Criteria & $\begin{array}{c}\text { Chamber } \\
\text { Type }\end{array}$ & \multicolumn{2}{|c|}{ TRS 398} & \multicolumn{2}{|c|}{ AAPM TG-51 } & \multicolumn{2}{|c|}{ DIN 6800-2 } \\
\hline & & Electron & Photon & Electron & Photon & Electron & Photon \\
\hline \multirow{2}{*}{$\begin{array}{l}\text { Chamber } \\
\text { position }\end{array}$} & Cylindrical & At $Z_{r e f}+r / 2$ & At $Z_{r e f}$ & At $Z_{r e f}$ & At $Z_{r e f}$ & $\begin{array}{c}\text { At } Z_{r e f}+ \\
r / 2\end{array}$ & At $Z_{r e f}+r / 2$ \\
\hline & $\begin{array}{c}\text { Plane } \\
\text { parallel }\end{array}$ & \multicolumn{2}{|c|}{ At $Z_{r e f}$} & \multicolumn{2}{|c|}{ At $Z_{r e f}$} & \multicolumn{2}{|r|}{ At $Z_{r e f}$} \\
\hline \multirow[b]{2}{*}{ Beam quality } & Cylindrical & & & specified & & specified & \\
\hline & $\begin{array}{l}\text { Plane } \\
\text { parallel }\end{array}$ & $\begin{array}{l}\text { specified by } \\
\text { the half-value } \\
\text { of the depth } \\
\text { dose in water } \\
\quad \mathrm{R}_{50}\end{array}$ & $\begin{array}{l}\text { specified by } \\
\text { the tissue } \\
\text { phantom } \\
\text { ratio } \\
\mathrm{TPR}_{20,10}\end{array}$ & $\begin{array}{l}\text { half- } \\
\text { value of } \\
\text { the } \\
\text { depth } \\
\text { dose in } \\
\text { water } \\
\mathrm{R}_{50}\end{array}$ & $\begin{array}{l}\text { specified } \\
\text { by } \\
\% d d(10)_{\mathrm{X}}\end{array}$ & $\begin{array}{l}\text { half- } \\
\text { value of } \\
\text { the } \\
\text { depth } \\
\text { dose in } \\
\text { water } \\
\mathrm{R}_{50}\end{array}$ & $\begin{array}{c}\text { specified by } \\
Q=1.2661 \frac{M_{20}}{M_{10}}-0.0595\end{array}$ \\
\hline \multirow[b]{2}{*}{ Value of $T_{o}$} & Cylindrical & \multirow{2}{*}{\multicolumn{2}{|c|}{$20^{\circ} \mathrm{C}$}} & \multirow{2}{*}{\multicolumn{2}{|c|}{$22{ }^{\circ} \mathrm{C}$}} & \multirow{2}{*}{\multicolumn{2}{|c|}{$20{ }^{\circ} \mathrm{C}$}} \\
\hline & $\begin{array}{c}\text { Plane } \\
\text { parallel }\end{array}$ & & & & & & \\
\hline \multirow{2}{*}{$\begin{array}{l}\text { Ion } \\
\text { recombination } \\
\text { correction } \\
\text { factor }\end{array}$} & Cylindrical & \multirow{2}{*}{\multicolumn{2}{|c|}{$K_{s}=a_{0}+a_{1}\left(\frac{M_{1}}{M_{2}}\right)+a_{2}\left(\frac{M_{1}}{M_{2}}\right)^{2}$}} & \multirow{2}{*}{\multicolumn{2}{|c|}{$P_{\text {ion }}=\frac{1-\frac{V_{\mathrm{H}}}{V_{\mathrm{L}}}}{\frac{M_{\text {raw }}^{\mathrm{H}}}{M_{\text {raw }}^{\mathrm{L}}}-\frac{V_{\mathrm{H}}}{V_{\mathrm{L}}}}$}} & \multirow{2}{*}{\multicolumn{2}{|c|}{$K_{S}=\frac{\frac{U_{1}}{U_{2}}-1}{\frac{U_{1}}{U_{2}}-\frac{M u_{1}}{M u_{2}}}$}} \\
\hline & $\begin{array}{c}\text { Plane } \\
\text { parallel }\end{array}$ & & & & & & \\
\hline $\begin{array}{l}\text { Chamber } \\
\text { positioning } \\
\text { correction }\end{array}$ & Cylindrical & \multicolumn{2}{|c|}{ none } & \multicolumn{2}{|c|}{ none } & \multicolumn{2}{|c|}{$K_{r}=1+|\delta| . r / 2$} \\
\hline
\end{tabular}

\section{RESULTS}

Calibration of Ionization Chambers

The calibration factors of Markus, A10 and FC65-G are listed in Table 2.

Table 2. Calibration factors of Markus, A10 and FC65-G

\begin{tabular}{|c|c|c|c|c|}
\hline \multirow[b]{2}{*}{ Chamber Model } & \multirow[b]{2}{*}{$\begin{array}{l}\text { Chamber } \\
\text { Serial No. }\end{array}$} & \multicolumn{2}{|c|}{$\begin{array}{c}\text { Calibration factor in } \\
\text { Gy/nc }\end{array}$} & \multirow[b]{2}{*}{ Variation (\%) } \\
\hline & & $\begin{array}{c}\text { Certified by } \\
\text { (Physikalisch- } \\
\text { Techische } \\
\text { Bundesanstalt) PTB }\end{array}$ & $\begin{array}{l}\text { Experimentally } \\
\text { found }\end{array}$ & \\
\hline PTW23343 Markus & 3941 & 0.5448 & 0.5349 & 1.8200 \\
\hline Exradin A10 & XC110304 & 0.6087 & 0.6047 & 0.6600 \\
\hline IBA FC65-G & 2009 & 0.0476 & 0.0477 & 0.1900 \\
\hline
\end{tabular}


Absorbed dose to water for Photon beam

Absorbed dose to water according to different protocols

\begin{tabular}{|c|c|}
\hline TRS 398 & $\begin{aligned} M_{Q}= & M_{\text {raw }} \times K_{T P} \times K_{\text {elec }} \times K_{\text {pol }} \times K_{S} \\
& D_{w, Q}=M_{Q} \times N_{D, w, Q_{0}} \times K_{Q}\end{aligned}$ \\
\hline TG 51 & $\begin{array}{c}M=M_{\text {raw }} \times P_{T P} \times P_{\text {elec }} \times P_{\text {pol }} \times P_{\text {ion }} \\
K_{Q}=P_{g r}^{Q} \times K_{R_{50}} \\
K_{R_{50}}=K_{R_{50}}^{\prime} \times K_{\text {ecal }} \\
D_{w, Q}=M \times N_{D, w, Q_{0}} \times K_{Q}\end{array}$ \\
\hline DIN 6800-2 & $\begin{array}{c}M_{Q}=M \times K_{\rho} \times K_{p} \times K_{r} \times K_{s} \\
k_{E}=k_{E}^{\prime} \times k_{E}^{\prime \prime} \\
k_{E}^{\prime}=1.106-0.1312\left(R_{50}\right)^{0.214} \\
k_{E}^{\prime \prime}=0.982\left(P_{c a v}\right)_{R_{50}} \\
\left(P_{c a v}\right)_{R_{50}}=1-0.037 e^{-0.27 R_{50}} \\
D_{w, Q}=M_{Q} \times N_{D, w, Q_{0}} \times K_{Q}\end{array}$ \\
\hline
\end{tabular}

a. Beam quality.

The measurement of $\mathrm{K}_{\mathrm{Q}}$ using three different protocols are presented in Table 3.

Table 3. Measurement of $\mathrm{K}_{\mathrm{Q}}$

\begin{tabular}{|c|c|c|c|}
\hline \multirow{2}{*}{ Energy (MV) } & \multicolumn{3}{|c|}{$K_{Q}$} \\
\cline { 2 - 4 } & IAEA TRS-398 & AAPM TG-51 & DIN 6800-2 \\
\hline $\mathbf{6}$ & 0.996 & 0.992 & 0.993 \\
\hline $\mathbf{1 5}$ & 0.981 & 0.976 & 0.977 \\
\hline
\end{tabular}

\section{b. Comparison among protocols.}

To make a comparison among protocols, we considered three main correction factors: pressure temperature correction, ion recombination correction and polarity correction factors. The values of these parameters are listed in Table 4.

Table 4. Values of pressure temperature, ion recombination and polarity correction factor

\begin{tabular}{|c|c|c|c|c|}
\hline \multicolumn{5}{|c|}{$\mathrm{K}_{\mathrm{tp}}$} \\
\hline Chamber & IAEA TRS 398 & AAPM TG 51 & \multicolumn{2}{|c|}{ DIN6800-2 } \\
\hline FC65-G (2005)* & 1.0078 & 1.0013 & \multicolumn{2}{|c|}{1.0081} \\
\hline FC65-G (2009)* & 1.0080 & 1.0015 & \multicolumn{2}{|c|}{1.0082} \\
\hline \multicolumn{5}{|c|}{$\mathbf{k}_{\mathrm{s}}$} \\
\hline Chamber & Energy (MV) & IAEA TRS 398 & AAPM TG-51 & DIN 6800-2 \\
\hline \multirow{2}{*}{ FC65-G (2005)* } & 6 & 1.0048 & 1.0050 & 1.0054 \\
\hline & 15 & 1.0063 & 1.0065 & 1.0078 \\
\hline \multirow{2}{*}{ FC65-G (2009)* } & 6 & 1.0027 & 1.0028 & 1.0027 \\
\hline & 15 & 1.0061 & 1.0064 & 1.0065 \\
\hline \multicolumn{5}{|c|}{$\mathbf{k}_{\text {pol }}$} \\
\hline Chamber & Energy (MV) & IAEA TRS-398 & AAPM TG-51 & DIN 6800-2 \\
\hline \multirow{2}{*}{ FC65-G (2005)* } & 6 & 1.0018 & 1.0018 & 1.0011 \\
\hline & 15 & 1.0009 & 1.0009 & 0.9993 \\
\hline \multirow{2}{*}{ FC65-G (2009)* } & 6 & 1.0017 & 1.0017 & 1.0011 \\
\hline & 15 & 1.0009 & 1.0009 & 1.0006 \\
\hline
\end{tabular}

*Here FC65-G (2005) and (2009) represents serial number.

A comparison of the maximum dose depths $\left(D_{\max }\right)$ measured with three different protocols is presented in Table 5. 
Studies of Dosimetry Protocols for Accelerated Photons and Electrons...

Table 5. Comparison of maximum dose depth $\left(D_{\max }\right)$ measured with three different protocols

\begin{tabular}{|c|c|c|c|c|c|c|c|}
\hline \multirow[b]{2}{*}{ Chamber } & \multirow[b]{2}{*}{$\begin{array}{c}\text { Energy } \\
\text { (MV) }\end{array}$} & \multicolumn{3}{|c|}{$D_{\max }$} & \multicolumn{3}{|c|}{ Deviation $(\%)$ in between } \\
\hline & & $\begin{array}{c}\text { IAEA TRS- } \\
398\end{array}$ & AAPM TG51 & DIN 6800-2 & $\begin{array}{c}\text { TRS-398 } \\
\& \\
\text { AAPM } \\
\text { TG51 }\end{array}$ & $\begin{array}{c}\text { AAPM } \\
\text { TG51 \& } \\
\text { DIN6800-2 }\end{array}$ & $\begin{array}{l}\text { DIN } \\
\text { 6800-2 \& } \\
\text { TRS-398 }\end{array}$ \\
\hline \multirow{2}{*}{$\begin{array}{c}\text { FC65-G } \\
(2005)\end{array}$} & 6 & $9.962 \times 10^{-03}$ & $9.859 \times 10^{-03}$ & $9.940 \times 10^{-03}$ & 1.03 & 0.82 & 0.22 \\
\hline & 15 & $9.882 \times 10^{-03}$ & $9.765 \times 10^{-03}$ & $9.917 \times 10^{-03}$ & 1.18 & 1.56 & 0.36 \\
\hline \multirow{2}{*}{$\begin{array}{c}\text { FC65-G } \\
(2009)\end{array}$} & 6 & $9.847 \times 10^{-03}$ & $9.745 \times 10^{-03}$ & $9.872 \times 10^{-03}$ & 1.03 & 1.29 & 0.26 \\
\hline & 15 & $9.816 \times 10^{-03}$ & $9.700 \times 10^{-03}$ & $9.856 \times 10^{-03}$ & 1.18 & 1.56 & 0.41 \\
\hline
\end{tabular}

We found that the percentage of the depth dose increases with increasing of energy, and the maximum dose $D_{\max }$ decreases. This is because the main influencing correction factor $K_{Q}$ decreases with increasing energy. The variation of the maximum dose depth at $D_{\max }$ for FC65G (2005) and FC65G (2009) according to IAEA TRS 398 and AAPM TG 51 was found to be $1.18 \%$ and $1.03 \%$ in 15 and $6 \mathrm{MV}$ photon energies respectively. However, in DIN $6800-2$ the variation of dose at $D_{\max }$ for FC65G (2005) and FC65G (2009) was found to be less than $0.5 \%$ in both 6 and 15 MV photon energies.

\section{a. PDD Curves.}

\section{Absorbed dose to water for Electron beam}

The PDD curves were observed at energies of 4, 6, 9, 12 and $15 \mathrm{MeV}$ for Clinac 2300CD, and at energies of 6, 9, 12 and $15 \mathrm{MeV}$ for DHX-3186. All comparative curves for limited length are shown in Figures 1 and 2. Since the electron beam has significantly low penetration power the reference depth for an electron is close to the phantom water surface.

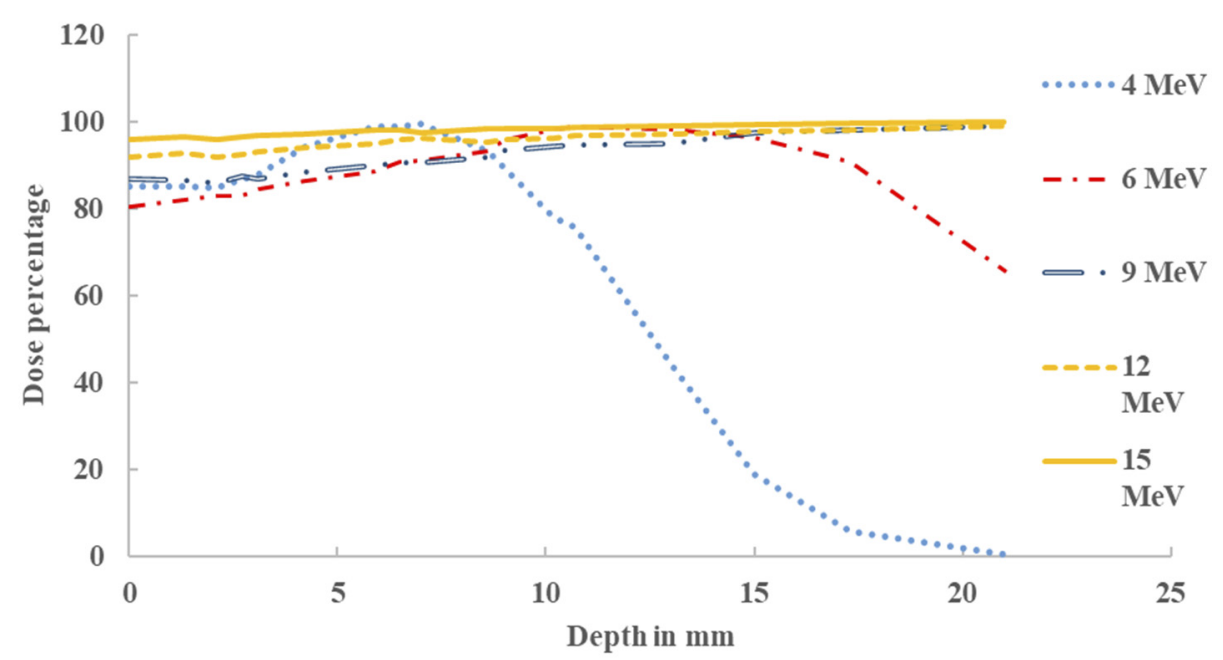

Figure 1. PDD curves for 4, 6, 9, 12 and $15 \mathrm{MeV}$ electron beams delivered from 2300CD Clinac

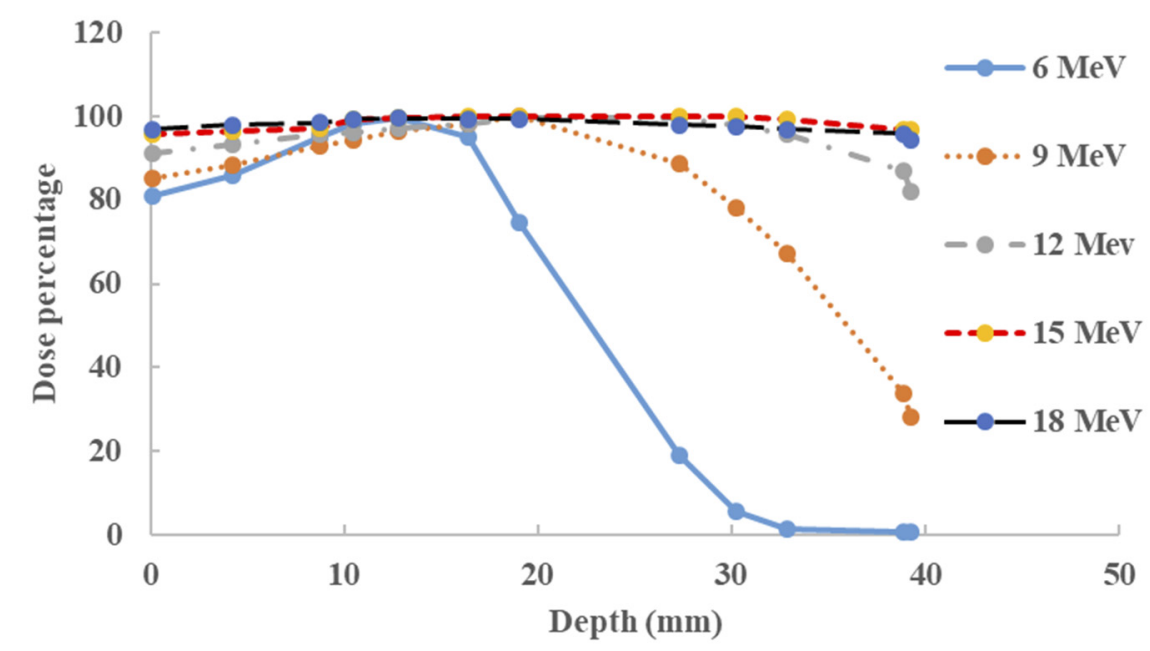

Figure 2. PDD curves for 6, 9, 12, 15 and $18 \mathrm{MeV}$ electron beams delivered from DHX-3186 Clinac

The dose percentage with respect to the energy and depth is presented in Table 6. 
Table 6. Dose percentage with respect to energy and depth

\begin{tabular}{|c|c|c|c|}
\hline Clinac & Energy (MV) & $Z_{r e f}(\mathrm{~cm})$ & Dose (\%) \\
\hline \multirow{5}{*}{ 2300CD } & 4 & 0.64 & 99.60 \\
\hline & 6 & 1.29 & 99.70 \\
\hline & 9 & 2.02 & 100.00 \\
\hline & 12 & 2.89 & 99.30 \\
\hline & 15 & 3.69 & 97.80 \\
\hline \multirow{4}{*}{ DHX-3186 } & 6 & 1.29 & 99.80 \\
\hline & 9 & 2.02 & 100.00 \\
\hline & 12 & 2.89 & 99.50 \\
\hline & 15 & 3.69 & 98.70 \\
\hline
\end{tabular}

\section{Comparison among protocols}

The PTW TM23343 Markus chamber was used to compare three protocols IAEA TRS 398, AAPM TG51 and DIN 6800-2. The correction factors for the electron beam are listed in table 7.

Table 7. Measurement of the correction factors for the electron beam

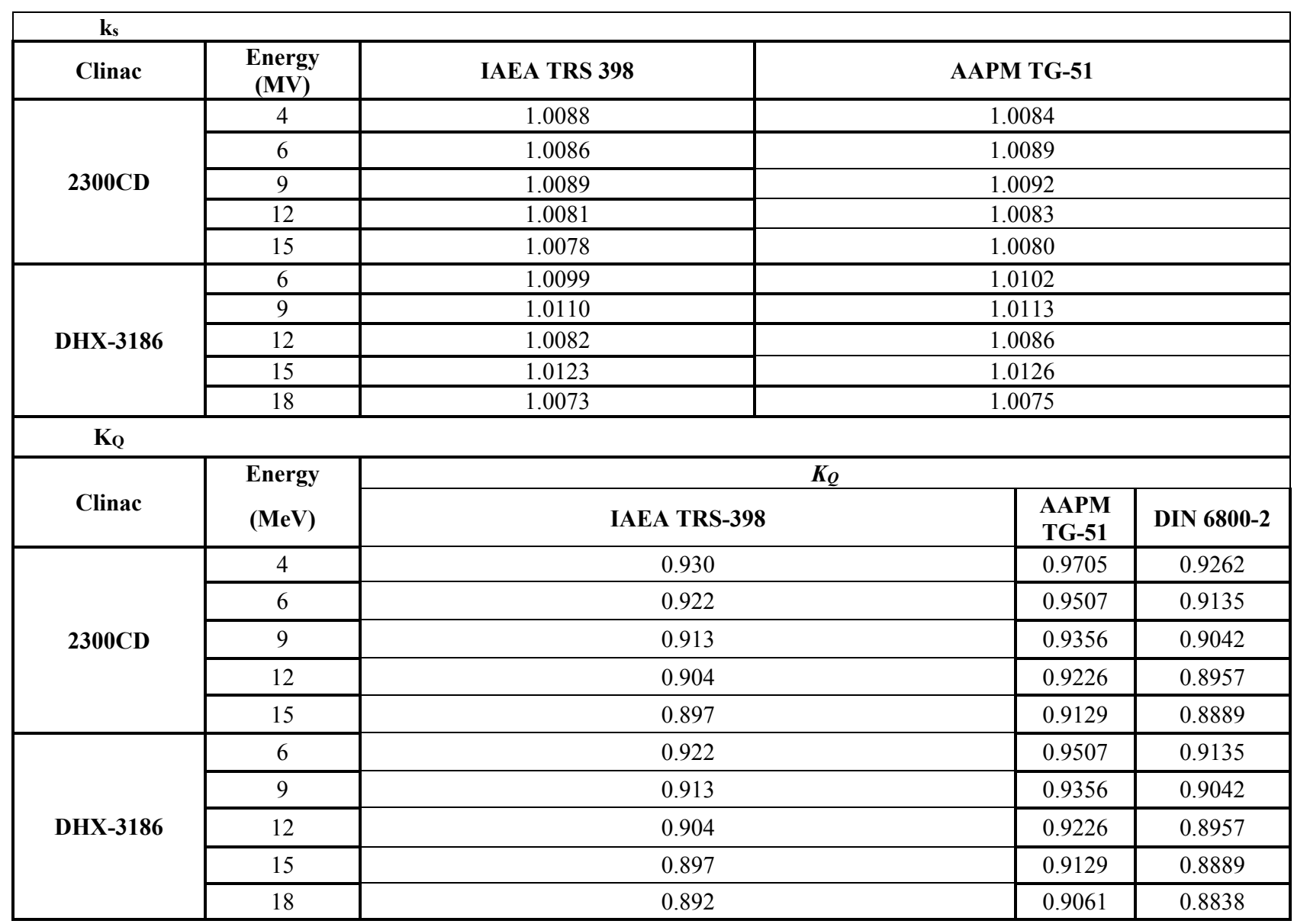

\section{Uncertainty in Dose Measurement}

For the photon beam the total uncertainty in the measurement of absorbed dose to water was approximately similar for FC65-G (2005) and (2009) which was $\pm 0.57 \%(k=1)$ for both 6 and $15 \mathrm{MV}$. Our work provides better result than that of Castro P et al ${ }^{3}$. For electron beam using the PTW TM23343 chamber, the total uncertainty in the absorbed dose to water in Clinac $2300 \mathrm{CD}$ were $\pm 1.74 \%, \pm 1.09 \%, \pm 0.92 \%, \pm 0.85 \%$ and $\pm 0.82 \%$ for $4,6,9,12$ and $15 \mathrm{MeV}$ respectively and that in Clinac DHX-3186 were $\pm 1.09 \%, \pm 0.94 \%, \pm 0.86 \%, \pm 0.84 \%$ and $\pm 0.80 \%$ for $6,9,12,15$ and $18 \mathrm{MeV}$ respectively $(k=1)$. In contrast using the Exradin A10 chamber for electron dosimetry, the total uncertainty in the absorbed dose to water in Clinac 2300CD were $\pm 1.67 \%, \pm 0.97 \%, \pm 0.78 \%, \pm 0.69 \%$ and $\pm 0.65 \%$ for $4,6,9,12$ and 15 $\mathrm{MeV}$ respectively and that in Clinac DHX-3186 were $\pm 0.96 \%, \pm 0.78 \%, \pm 0.76 \%, \pm 0.68 \%$ and $\pm 0.69 \%$ for $6,9,12,15$ and $18 \mathrm{MeV}$ respectively $(k=1)$. 


\section{DISCUSSIONS}

In general, the discrepancies in the values of beam quality, $\mathrm{K}_{\mathrm{Q}}$ and $D_{\max }$ for various protocols exhibited in a deceasing trend for the electron beam with the increase of energy. In contrast, for the comparative study with various chambers, the variation in $D_{\max }$ also exhibited in a decreasing trend with energy for both the accelerated photon and electron. The vital influencing factor for deviations among the protocols as well as between the chambers was the beam quality conversion factor $K_{Q}$. The deviation can be resolved if the chambers can be calibrated at their respective electron or photon beam quality rather than at ${ }^{60} \mathrm{Co}$. Our measured correction factors, according to the TG-51, TRS-398 and DIN 6800-2 protocols were in good agreement with previous published works $[4,6,14,15,16]$.

\section{CONCLUSIONS}

In this study, it was experimentally observed that the TRS 398 protocol is in good agreement with DIN 6800-2 rather than TG51 because of the measurement technique and correction factors included with the protocol. The experimental uncertainty (Type A and B) included in the measurement is below that of the previously published and recommended works $[6,17]$. In this work we found that, some uncertainties would be minimized if the chambers calibrated with the photon beam delivered from the medical LINAC rather than the ${ }^{60} \mathrm{Co}$ beam.

Compliance with Ethical Standards: This article does not contain any studies with human participants performed by any of the authors.

Funding: None

Conflict of Interest: All authors declare that they have no conflict of interest

\section{ORCID IDs}

(D)AKM Moinul Haque Meaze, https://orcid.org/0000-0002-1526-2113; (DSantunu Purohit, https://orcid.org/0000-0002-0029-995X; (D)Md. Shakilur Rahman, https://orcid.org/0000-0002-7873-7999; (D)Abdus Sattar, https://orcid.org/0000-0003-3863-7253;

(DSM Enamul Kabir, https://orcid.org/0000-0002-9684-4966; (D)Kamrunnahar Kali, https://orcid.org/0000-0002-9284-9516;

(D) Md. Kawchar Ahmed Patwary, https://orcid.org/0000-0002-6150-9113;

(D) Md. Jubayer Rahman Akhand, https://orcid.org/0000-0002-4406-0369

\section{REFERENCES}

[1] K.A. Paskalev, J.P. Seuntjens, H.J. Patrocinio, and E.B. Podgorsak, Med Phys. 30(2), 111-118 (2003), https://doi.org/10.1118/1.1536290.

[2] A.J. D. Scott, A.E. Nahum, and J.D. Fenwick, Am. Assoc. Phys. Med. 35(10), 4671-4684 (2008), https://doi.org/10.1118/1.2975223.

[3] P. Castro, F.G Vicente, C. Minguez, A. Floriano, D. Sevillano, L. Perez, and J.J. Torres. Appl. Clinical Medical Phys. 9(1), 7086 (2008), https://dx.doi.org/10.1120\%2Fjacmp.v9i1.2676.

[4] M.S. Huq, P. Andreo, and H. Song. Physics in Medicine and Biology, 46(11), 2985-3006 (2001), https://doi.org/10.1088/00319155/46/11/315.

[5] H. Palmans, L. Nafaa, N. Patoul, J-M. Denis, M. Tomsej, and S. Vynckier, Physics in Medicine and Biology, 48(9), 1091-1107 (2003), https://doi.org/10.1088/0031-9155/48/9/301.

[6] F. Araki, and H.D. Kubo, Med Phys. 29(5), 857-868 (2002), https://doi.org/10.1118/1.1470208.

[7] S.S. Al-Ahbabi, D.A. Bradley, M. Beyomi, Z. Alkatib, S. Adhaheri, M. Darmaki, and A. Nisbet, Appl Radiat. Isot. 70(7), 13311336 (2012), https://doi.org/10.1016/j.apradiso.2011.11.065.

[8] Radiotherapy Ionization Chamber Calibration Procedures at the IAEA Dosimetry Laboratory, http://wwwnaweb.iaea.org/nahu/dmrp/documents/DOLP.011_Appendix_3A_to_Calibration_certificate_rev6.pdf.

[9] J. Medin, P. Andreo, and S. Vynckier, Phys Med Biol. 45(11), 3195-3211 (2000), https://doi.org/10.1088/0031-9155/45/11/306.

[10] S.R.M. Mahdavi, M. Mahdavi, H. Alijanzadeh, M. Zabihzadeh, and A. Mostaar, Iran J. Radiat. Res. 10(1), 43-51 (2012), https://www.sid.ir/FileServer/JE/92620120106.pdf.

[11] Absorbed Dose Determination in External Beam Radiotherapy: An International Code of Practice for Dosimetry based on Standards of Absorbed Dose to Water. TRS No.398. (International Atomic Energy Agency, Vienna, 2001), https://wwwpub.iaea.org/MTCD/Publications/PDF/TRS398_scr.pdf.

[12] Calibration of dosimeters used in radiotherapy. TRS No.374. (International Atomic Energy Agency, Vienna, 1994), https://inis.iaea.org/collection/NCLCollectionStore/_Public/26/037/26037970.pdf.

[13] P.R. Almond, P.J. Biggs, B.M. Coursey, W.F. Hanson, M.S. Huq, R. Nath, and D.W.O. Rogers, Med Phys. 26(9), 1847-1870 (1999), https://doi.org/10.1118/1.598691.

[14] G.A. Zakaria, W. Schuette, and C. Younan, Biomed Imaging Interv. J. 7(2), 1-10 (2011), https://www.ncbi.nlm.nih.gov/ pmc/articles/PMC3265153/pdf/biij-07-e15.pdf.

[15] G.A. Zakaria, and W. Schütte, Zeitschrift für medizinische physic, 13(4), 281-289 (2003), https://doi.org/10.1078/0939-388900182.

[16] G.A. Zakaria, and W. Schütte, J. Med Phys. 32(1), 3-11 (2007), https://doi.org/10.4103/0971-6203.31143.

[17] D.I. Thwaites, B. Mijnheer, and J.A. Mills, in: Radiation Oncology Physics: A Handbook for Teachers and Students, edited by E.B. Podgorsak (International Atomic Energy Agency, Vienna, 2005), pp. 407-450, http://wwwnaweb.iaea.org/nahu/DMRP/documents/Chapter12.pdf. 


\author{
ДОСЛІДЖЕННЯ ПРОТОКОЛІВ ДОЗИМЕТРІЇ ДЛЯ ПРИСКОРЕНИХ ФОТОНІВ І ЕЛЕКТРОНІВ \\ ВІД МЕДИЧНОГО ЛІНІЙНОГО ПРИСКОРЮВАЧА \\ АКМ Мойнул Гаку Миз ${ }^{a}$ Сантуну Пурохіта \\ М. Кавчар Ахмед Патварі ${ }^{\mathrm{d}}$, Камруннахар Калі ${ }^{\mathrm{d}}$, М. Джубайер Рахман Аханд \\ ${ }^{a}$ Фізичний факультет, Університету Чіттагонгу, Бангладеш

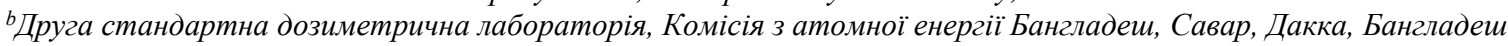 \\ ${ }^{c}$ Наиіональний інститут досліджень раку, Дакка, Бангладеш \\ ${ }^{d}$ Фізичний факультет, Університет Комілла, Бангладеш \\ ${ }^{e}$ Військова Академія Бангладеш, Бхатіарі, Читтагонг, Бангладеш
}

Особливу увагу в цій статті зосереджено на порівняльному дослідженні дозиметричних протоколів променевої терапії для прискорених фотонів та електронів, що надходять з лінійного медичного прискорювача (LINAC). У цьому дослідженні було проведено порівняння між протоколами (TRS 398, DIN 6800-2 і TG 51) як для електрона, так і для фотона, що надійшли 3 Clinac 2300CD i Clinac DHX 3186. Ми використовували пучки фотонів з енергіями 6 та 15 МВ та електронні пучки з енергіями 4, 6, 9, 12, 15 та $18 \mathrm{MeB}$ для обох медичних лінійних прискорювачів. У випадку з Clinaс максимальні відхилення відносної дози при $\mathrm{D}_{\max }$ для пучка фотонів (15 MB) серед протоколів становило 1,18\% між TRS-398 i TG-51, 1,56\% між TG-51 i DIN 6800-2, та 0,41\% між TRS-398 та DIN 6800-2. I навпаки, ці відхилення становили 3,67\% між TRS-398 i TG-51, 3,92\% між TG51 i DIN 6800-2 для 4 MeB, i 0,95\% між TRS-398 i DIN 6800-2 у випадку Clinac 2300 CD для PTW Markus та Exradin A10. При вимірюванні максимальної глибини поглинутої дози у воді за допомогою трьох протоколів спостерігались максимальні відхилення між TRS 398 та TG-51, а також TG51 та DIN 6800-2.

КЛЮЧОВІ СЛОВА: TRS (Серія технічних звітів), TG (Цільова група), DIN (Німецький інститут стандартизаціi). 